\title{
Europski stup socijalnih prava ${ }^{1}$
}

UDK: 364.01(4)

doi: 10.3935/rsp.v26i1.1631

Izazovi ekonomske i socijalne nesigurnosti prepoznati su kao prioritet u vremenu u kojem se tržišta rada i društva brzo razvijaju, a globalizacija, digitalna revolucija, promjene u obrascima rada te društvena $\mathrm{i}$ demografska kretanja donose nove mogućnosti i izazove (poput izrazite nejednakosti, dugotrajne nezaposlenosti i nezaposlenosti mladih te međugeneracijske solidarnosti). Budući da su gospodarski i društveni napredak povezani, uspostava Europskog stupa socijalnih prava poboljšavanjem europske konkurentnosti i poticanjem ulaganja, otvaranjem radnih mjesta i socijalne kohezije trebala bi biti dio sveobuhvatnijih napora u izgradnji uključivijeg i održivijeg modela rasta s pravednim tržištem rada i socijalnom državom.

U takvim okolnostima su Europski parlament, Vijeće i Komisija na Socijalnom samitu za pravedna radna mjesta i rast (Social Summit for Fair Jobs and Growth), održanom u Gothenburgu, Švedska, 17. studenog 2017. ${ }^{2}$ naglasili potrebu da se ljudi stave na prvo mjesto i predstavili Europski stup socijalnih prava koji se sastoji od tri cjeline i 20 načela koji su unutar svake cjeline podijeljeni na nekoliko tema.

\section{GLAVNE RACIONALE POGLAVLJA EUROPSKOG STUPA SOCIJALNIH PRAVA}

\section{POGLAVLJE I. JEDNAKE MOGUĆNOSTI I PRISTUP TRŽIŠTU RADA}

Iako je u Europskoj uniji zaposlenost na najvećoj, a nezaposlenost na najmanjoj razini od izbivanja krize, nezaposlenost varira između zemalja članica. Kao posebni izazovi prepoznaju se nezaposlenost mladih i dugotrajna nezaposlenost. Također, iako zaposlenost žena i starijih radnika raste, očekuje se dodatan rad na angažiranju njihovih kapaciteta na tržištu rada kao i onih migranata te osoba s invaliditetom.

Tehnologije mijenjaju narav poslova čineći digitalne vještine sve važnijima, no danas je najviše poslova u uslužnoj industriji. Mijenjaju se i uvjeti zaposlenja. Izazovi nalaženja i zadržavanja posla uključuju i razvoj potrebnih vještina, ali i nepovoljne porezne sustave, diskriminaciju različitih skupina na tržištu rada ili pak usklađivanje obiteljskih i obaveza na tržištu rada.

\footnotetext{
${ }^{1}$ Uvodni dio teksta, kao i korigirani prijevod su, s nakanom da se aktualizira Europski stup socijalnih prava u Hrvatskoj, nastali u okviru projekta Socijalno vijeće Grada Zagreba koji je uz financiranje Grada Zagreba provodila udruga CERANEO.

${ }^{2}$ Povodom izjave za prvu godišnjicu proglašavanja stupa socijalnih prava predsjednik Europske komisije Juncker naglasio je njegovu implementaciju i najavio osnaženi i širi Europski socijalni fond: http://ec.europa. $\mathrm{eu} /$ social/main.jsp?langId=en\&catId=89\&newsId=9240\&furtherNews=yes.
} 


\section{POGLAVLJE II. PRAVEDNI RADNI UVJETI}

Zaposlenost na neodređeno vrijeme s punim radnim vremenom i dalje prevladava u Europi. Međutim, nove forme rada i tehnologije mijenjaju prakse u svijetu rada što utječe na nove tipove ugovora i naknada, kao i na promjenu kultura poduzeća. Obrasci karijera su sve raznolikiji te je sve veća mobilnost između profesija i geografskih lokacija. Ove transformacije povezane s društvenim i demografskim promjenama dovode do izazova u usklađivanju profesionalnog i obiteljskog života kao i novih obveza za socijalnu državu. Nestandardno zaposlenje raste, posebice među skupinama s niskim prihodima kao i onima u prekarnim i nesigurnim radnim uvjetima. To dovodi do povećanja broja siromašnih zaposlenih osoba u nekim europskim zemljama. Socijalni dijalog je ključan za osnaživanje socijalnih prava i promicanje održivog razvoja.

\section{POGLAVLJE III. SOCIJALNA ZAŠTITA I UKLJUČENOST}

Kako se karakter rada transformira, neke se profesije stvaraju, a neke nestaju, što brzo mijenja dinamiku vještina potrebnih na tržištu rada. Iako obrazovna razina generalno raste, tranzicija iz obrazovanja na tržište rada je izazovna, posebno za mlade i nisko obrazovane radnike, kao i migrante. Često postoje barijere ponovnom ulasku žena na tržište rada nakon brige za djecu. Veći broj tranzicija koje se događaju unutar radnih karijera postavljaju i izazove cjeloživotnog razvoja vještina/obrazovanja. Mobilni radni životi imaju implikacije i za socijalnu sigurnost i prava na osposobljavanje te socijalne, obrazovne i politike tržišta rada kao i na institucije i socijalne partnere koji se trebaju nasloviti i prilagoditi novim realnostima.
Europskim stupom socijalnih prava Europska komisija stavlja naglasak na razvoj ambicioznije europske socijalne i politike zapošljavanja. Stup socijalnih prava treba doprinijeti razvoju konkurentnog socijalno tržišnog gospodarstva te prevladati krizu. $\mathrm{Na}$ socijalnu politiku gleda se kao na produktivnu činjenicu koja će doprinijeti dobro funkcionirajućem poštenom tržištu rada, doprinijet će rastu produktivnosti i jačanju socijalne kohezije te povećanju životnog standarda građana.

Dokument Social priorities under the Juncker Commission (2018.) sumira politike, zakonodavne promjene, inicijative i aktivnosti financiranja povezane s Europskim stupom socijalnih prava. Navodi ih se trideset i šest u nekoliko područja poput pravednih i primjenjivih pravila za mobilnost radnika, ulaganja u mlade i vještine, obnavljanja socijalnog dijaloga, ali i širih aspekta poput jačanja zajedničkih vrijednosti, prepoznavanja socijalne dimenzije u svim politikama $\mathrm{i}$ modernizacije »socijalnog zakonodavstva «. Navode se i neki od pomaka koji su se dogodili u Europskoj uniji među kojima se ističe rekordna razina zaposlenosti u Europi.

Osim toga, ovogodišnja analiza Social policy in the European Union: State of play 2018 uvelike razmatra Europski stup socijalnih prava (European Trade Union Institute, 2018.). Dokument vidi mogućnosti oživljavanja Europske socijalne agende kroz Europski stup socijalnih prava iako se takva budućnost za sada čini nesigurnom. Efektivnost stupa može se sagledavati i prema tome koliko će biti »kompas « u procesu Europskog semestra, ali i utjecati na EU makroekonomske i fiskalne politike te biti okvir EU socijalnih politika.

Vlada Republike Hrvatske izrazila je podršku Europskom stupu socijalnih prava smatrajući da bi trebao imati značajan utjecaj na nacionalne politike ${ }^{3}$. Kako do-

${ }^{3}$ https://vlada.gov.hr/vijesti/predsjednik-vlade-na-social-summitu-u-goteborgu-hrvatska-snazno-podupire-europski-stup-socijalnih-prava/22868. 
kument nema suviše formalnih pokazatelja praćenja ${ }^{4}$, treba budno pratiti koliko će biti vodilja domaćih donositelja socijalnih politika u sljedećem vremenskom periodu.

\section{EUROPSKI STUP SOCIJALNIH PRAVA}

\section{Preambula ${ }^{5}$}

1. U skladu s člankom 3. Ugovora o Europskoj uniji, cilj je Unije, među ostalim, promicanje dobrobiti njezinih ljudi i rad na održivom razvoju Europe koji se temelji na uravnoteženom gospodarskom rastu i stabilnosti cijena, visoko konkurentnom socijalno tržišnom gospodarstvu u cilju pune zaposlenosti i društvenog napretka te visokoj razini zaštite i poboljšanja kvalitete okoliša. Unija suzbija socijalnu isključenost i diskriminaciju, promiče socijalnu pravdu i zaštitu, ravnopravnost žena i muškaraca, međugeneracijsku solidarnost i zaštitu prava djece.

2. U skladu s člankom 9. Ugovora o funkcioniranju Europske unije, Unija pri utvrđivanju i provedbi svojih politika i aktivnosti uzima u obzir zahtjeve povezane s promicanjem visoke razine zaposlenosti, jamstvom primjerene socijalne zaštite, borbom protiv socijalne isključenosti te visokom razinom obrazovanja, osposobljavanja i zaštite zdravlja ljudi.

3. Člankom 151. Ugovora o funkcioniranju Europske unije predviđa se da Unija i države članice, imajući na umu temeljna socijalna prava, kao što su ona određena u Europskoj socijalnoj povelji potpisanoj 18. listopada 1961. u Torinu te ona iz Povelje Zajednice o temeljnim socijalnim pravima radnika iz 1989., imaju za cilj promicanje zapošljavanja, poboljšanje životnih i radnih uvjeta, kako bi se na putu napretka omogućilo njihovo usklađivanje, odgovarajuću socijalnu zaštitu, socijalni dijalog, razvoj ljudskih potencijala u cilju trajne visoke stope zaposlenosti i borbe protiv isključenosti.

4. Člankom 152. Ugovora o funkcioniranju Europske unije predviđa se da Unija prepoznaje i promiče ulogu socijalnih partnera na svojoj razini, uzimajući u obzir raznolikost nacionalnih sustava. Unija je tu da olakšava dijalog među socijalnim partnerima poštujući njihovu autonomiju.

5. Poveljom Europske unije o temeljnim pravima, proglašenom 7. prosinca 2000. na sastanku Europskog vijeća u Nici, štite se i promiču brojna osnovna načela koja su ključna za europski socijalni model. Odredbe te Povelje naslovljene su institucijama, tijelima, uredima i agencijama Unije, uz poštovanje načela supsidijarnosti, te na države članice samo kada provode pravo Unije.

6. Ugovor o funkcioniranju Europske unije sadržava odredbe kojima se utvrđuju ovlasti Unije povezane s, među ostalim, slobodom kretanja radnika (članci 45. do 48.), pravom poslovnog nastana (članci 49. do 55.), socijalnom politikom (članci 151. do 161.), promicanjem socijalnog dijaloga (članak 154.), uključujući sklapanje i provedbu sporazuma na razini Unije (članak 155.), jednakim plaćama muškaraca i žena za jednak rad (članak 157.), doprinosom razvoju kvalitetnog obrazovanja i strukovnog osposobljavanja (članci 165. i 166.), djelovanjem Unije kojim se nadopunjuju nacionalne politike i promiče suradnja u području zdravstva (članak 168.), ekonomskom, socijalnom i teritorijalnom kohezijom (članci 174. do 178.), oblikovanjem i nadzorom pro-

\footnotetext{
${ }^{4}$ Osim platforme socijalnih pokazatelja koja će pratiti trendove i biti indikativna: https://composite-indicators.jrc.ec.europa.eu/social-scoreboard/.

${ }^{5}$ Ova verzija teksta Europskog stupa socijalnih prava predstavlja korigiranu verziju prijevoda koji se može pronaći na:https:/ec.europa.eu/commission/sites/beta-political/files/social-summit-european-pillar-social-rights-booklet_hr.pdf. U ovoj inačici korigirani su izrazi koji se smatraju adekvatnijima stručnom rječniku socijalne politike i uvriježenima u literaturi i praksi, a koji su bili manjkavi u originalnoj inačici prijevoda.
} 
vedbe općih smjernica ekonomskih politika (članak 121.), utvrđivanjem smjernica za zapošljavanje $\mathrm{i}$ ispitivanjem njihove provedbe (članak 148.) i, općenitije, usklađivanjem zakonodavstava (članci 114. do 117.).

7. Europski parlament pozvao je na uspostavu stabilnog Europskog stupa socijalnih prava kako bi se ojačala socijalna prava, kratkoročno i srednjoročno pozitivno utjecalo na živote ljudi te poduprla izgradnja Europe u 21. stoljeću. ${ }^{6}$ Čelnici 27 država članica naglasili su da je rješavanje ekonomske i socijalne nesigurnosti prioritet te su pozvali na stvaranje svijetle ekonomske budućnosti za sve, zaštitu našeg načina života i osiguravanje boljih mogućnosti za mlade. ${ }^{7}$ Celnici 27 država članica te Europskog vijeća, Europskog parlamenta i Europske komisije u Rimskoj deklaraciji obvezali su se raditi na ostvarivanju socijalne Europe. Ta se obveza temelji na načelu održivog rasta i promicanja gospodarskog i društvenog napretka te koheziji i konvergenciji, čuvajući pritom integritet unutarnjeg tržišta; Uniji koja u obzir uzima raznolikost nacionalnih sustava i ključnu ulogu socijalnih partnera; Uniji koja promiče ravnopravnost žena i muškaraca te prava i jednake mogućnosti za sve; Uniji koja se bori protiv nezaposlenosti, diskriminacije, socijalne isključenosti i siromaštva; Uniji u kojoj se mladima pruža najbolje obrazovanje i osposobljavanje te u kojoj oni mogu studirati i pronaći posao diljem kontinenta; Uniji koja čuva našu kulturnu baštinu i promiče kulturnu raznolikost. ${ }^{8}$ Socijalni partneri obvezali su se da će i dalje pridonositi Europi koja svojim radnicima i poduzećima donosi rezultate. ${ }^{9}$

8. Dovršetak jedinstvenog europskog tržišta posljednjih desetljeća pratio je razvoj čvrste socijalne stečevine, što je dovelo do napretka u slobodi kretanja, načinu života i radnim uvjetima, ravnopravnosti žena i muškaraca, zdravlju i sigurnosti na radu, socijalnoj zaštiti te obrazovanju i osposobljavanju. Uvođenje eura dalo je Uniji stabilnu zajedničku valutu kojom se koristi 340 milijuna građana u 19 država članica, što im olakšava svakodnevni život i štiti ih od financijske nestabilnosti. Unija se također znatno proširila, što je dovelo do brojnijih gospodarskih mogućnosti i promicanja društvenog napretka diljem kontinenta.

9. Tržišta rada i društva brzo se razvijaju, a globalizacija, digitalna revolucija, promjene u obrascima rada te društvena $\mathrm{i}$ demografska kretanja donose nove mogućnosti i izazove. Izazovi, kao što su izrazita nejednakost, dugotrajna nezaposlenost i nezaposlenost mladih te međugeneracijska solidarnost, često su slični u svim državama članicama, premda u različitim stupnjevima.

10. Europa je pokazala namjeru da prebrodi financijsku i gospodarsku krizu i, zahvaljujući odlučnim mjerama, gospodarstvo Unije sada je stabilnije, stope zaposlenosti rekordno su visoke, a nezaposlenost se kontinuirano smanjuje. Međutim, društvene posljedice krize, primjerice, nezaposlenost mladih, dugotrajna nezaposlenost i rizik od siromaštva, su dalekosežne i potrebno ih je hitno riješiti.

11. Zapošljavanje i društveni izazovi s kojima se Europa suočava u velikoj su mjeri posljedica relativno skromnog rasta koji je rezultat neiskorištenog potencijala u smislu sudjelovanja u zapošljavanju i produktivnosti. Budući da su gospodarski i društveni napredak povezani, uspostava Europskog stupa socijalnih prava poboljšavanjem europske konkurentnosti i poticanjem ulaganja, otvaranja radnih mjesta i socijalne

\footnotetext{
${ }^{6}$ Europski parlament, Rezolucija od 19. siječnja 2017. o Europskom stupu socijalnih prava, 2016/2095(INI).

${ }^{7}$ Deklaracija iz Bratislave od 16. rujna 2016.

${ }^{8}$ Rimska deklaracija od 25. ožujka 2017.

${ }^{9}$ Zajednička izjava socijalnih partnera od 24. ožujka 2017.
} 
kohezije trebala bi biti dio sveobuhvatnijih napora u izgradnji uključivijeg i održivijeg modela rasta.

12. Cilj Europskog stupa socijalnih prava je da služi kao vodič k učinkovitom zapošljavanju i socijalnim ishodima kada se odgovara na postojeće i buduće izazove koji su izravno usmjereni na ispunjavanje osnovnih ljudskih potreba te osiguravanje boljeg ostvarivanja i provođenja socijalnih prava.

13. Jača usmjerenost na ostvarivanje rezultata u području zapošljavanja i socijalnih učinaka osobito je važna radi povećanja opruživosti (eng. resilience) i jačanja ekonomske i monetarne unije. Zbog toga je Europski stup socijalnih prava konkretno zamišljen za euro područje, ali se odnosi na sve države članice.

14. Europski stup socijalnih prava odraz je načela i prava koji su ključni za pravedno i dobro funkcionirajuće tržišta rada i sustave socijalne skrbi u Europi 21. stoljeća. Njime se potvrđuju neka od prava koja su već sadržana u pravnoj stečevini Unije. Dodaju se i nova načela koja se odnose na izazove koji proizlaze iz društvenog, tehnološkog i ekonomskog razvoja. Kako bi postala pravno izvršiva, za ta načela i prava potrebno je prvo na odgovarajućoj razini donijeti namjenske mjere ili zakone.

15. Načela koja su utvrđena u Europskom stupu socijalnih prava odnose se na građane Unije i državljane trećih zemalja sa zakonitim boravkom u Uniji. Kada je određeno načelo povezano s radnicima, ono se odnosi na sve zaposlene osobe, neovisno o njihovu radnom statusu te načinu i trajanju rada.

16. Europski stup socijalnih prava ne sprečava države članice ili njihove socijalne partnere da uspostave ambicioznije socijalne standarde. Konkretno, ništa iz Europskog stupa socijalnih prava ne smije se tumačiti na način da se ograničavaju prava i načela kako su u svojim područjima primjene utvrđena pravom Unije ili međunarodnim pravom i međunarodnim sporazumima čije su Unija ili sve države članice stranke, uključujući Europsku socijalnu povelju potpisanu u Torinu 18. listopada 1961. i mjerodavne konvencije i preporuke Međunarodne organizacije rada, odnosno na način da se na ta prava i načela negativno utječe.

17. Uspostava Europskog stupa socijalnih prava zajednička je politička obveza i odgovornost. Europski stup socijalnih prava trebao bi se provesti na razini Unije i na razini država članica u okviru njihovih nadležnosti, uzimajući u obzir različite socioekonomske uvjete i raznolikost nacionalnih sustava uključujući ulogu socijalnih partnera, i u skladu s načelima supsidijarnosti i proporcionalnosti.

18. Na razini Unije Europski stup socijalnih prava ne podrazumijeva veće ovlasti i zadaće Unije od onih dodijeljenih Ugovorima. On bi se trebao provesti u okviru tih ovlasti.

19. Europskim stupom socijalnih prava poštuju se raznolikost kultura i tradicija europskih naroda te nacionalni identiteti država članica i organizacija njihovih javnih tijela na nacionalnoj, regionalnoj i lokalnoj razini. Konkretno, uspostavom Europskog stupa socijalnih prava ne utječe se na pravo država članica da utvrde osnovna načela svojih sustava socijalne sigurnosti i upravljaju svojim javnim financijama te se ne smije znatno utjecati na njihovu financijsku ravnotežu.

20. Socijalni dijalog ima središnju ulogu u jačanju socijalnih prava te održivog i uključivog rasta. Socijalni partneri na svim razinama imaju ključnu ulogu u ostvarivanju i provedbi Europskog stupa socijalnih prava u skladu sa svojom autonomijom u pregovorima i sklapanju sporazuma i pravom na kolektivno pregovaranje i kolektivno djelovanje. 


\section{POGLAVLJA EUROPSKOG STUPA SOCIJALNIH PRAVA}

\section{POGLAVLJE I. JEDNAKE MOGUĆNOSTI I PRISTUP TRŽIŠTU RADA}

\section{Obrazovanje, osposobljavanje i cjeloživotno učenje}

Svi imaju pravo na kvalitetno i uključivo obrazovanje, osposobljavanje i cjeloživotno učenje kako bi održali i stekli vještine s pomoću kojih mogu u cijelosti sudjelovati u društvu i uspješno ući na tržište rada.

\section{Rodna ravnopravnost}

a. Jednako postupanje i jednake mogućnosti žena i muškaraca moraju se osigurati i poticati u svim područjima, uključujući sudjelovanje na tržištu rada, uvjete zaposlenja i napredovanje u karijeri.

b. Žene i muškarci imaju pravo na jednaku plaću za rad jednake vrijednosti.

\section{Jednake mogućnosti}

Bez obzira na spol, rasnu ili etničku pripadnost, vjeru ili uvjerenje, invaliditet, dob ili spolnu orijentaciju, svi imaju pravo na jednako postupanje i jednake mogućnosti u pogledu zapošljavanja, socijalne zaštite, obrazovanja te pristupa dobrima i uslugama dostupnima javnosti. Potiču se jednake mogućnosti nedovoljno zastupljenih skupina.

\section{Aktivna potpora zapošljavanju}

a. Svi imaju pravo na pravovremenu i prilagođenu pomoć u poboljšavanju izgleda za zapošljavanje ili samozapošljavanje. To uključuje pravo na potporu pri traženju posla, osposobljavanju i prekvalifikaciji. Svi imaju pravo na prijenos socijalne zaštite i prava na osposobljavanje kada mijenjaju radno mjesto.

b. Mladi imaju pravo na kontinuirano obrazovanje, naukovanje, pripravništvo ili pouzdanu ponudu za posao u razdoblju od četiri mjeseca nakon gubitka posla ili prekida obrazovanja.

c. Nezaposleni imaju pravo na prilagođenu, neprekidnu i dosljednu potporu. Dugotrajno nezaposleni imaju pravo na detaljnu individualnu procjenu najkasnije 18 mjeseci od gubitka posla.

\section{POGLAVLJE II. PRAVEDNI RADNI UVJETI}

\section{Sigurno i prilagodljivo zaposlenje}

a. Bez obzira na vrstu i trajanje radnog odnosa radnici imaju pravo na pravedno i jednako postupanje u pogledu radnih uvjeta, pristupa socijalnoj zaštiti i osposobljavanju. Potiče se prijelaz prema zapošljavanju na neodređeno vrijeme.

b. U skladu sa zakonodavstvom i kolektivnim ugovorima osigurava se potrebna fleksibilnost poslodavaca da se brzo prilagode gospodarskim promjenama.

c. Potiču se inovativni oblici zapošljavanja kojima se osiguravaju kvalitetni radni uvjeti. Potiču se poduzetništvo i samozapošljavanje. Olakšava se profesionalna mobilnost.

d. Sprečava se sklapanje radnih odnosa s nesigurnim radnim uvjetima, uključujući zabranu zlouporabe nestandardnih ugovora. Probni rad trebao bi se zaključiti u razumnom roku

\section{Plaće}

a. Radnici imaju pravo na pravedne plaće s kojima se može dostojno živjeti.

b. Osigurava se primjerena minimalna plaća kojom se mogu zadovoljiti potrebe radnika i njihovih obitelji u određenim nacionalnim gospodarskim i društvenim uvjetima štiteći pristup zapošljavanju i poticajima za traženje zaposlenja. Sprečava se siromaštvo zaposlenih.

c. Sve se plaće utvrđuju transparentno i predvidljivo u skladu s nacionalnom 
praksom i poštujući autonomiju socijalnih partnera.

\section{Informacije o uvjetima zaposlenja i zaštita u slučaju dobivanja otkaza}

a. Radnici imaju pravo na početku zaposlenja u pisanom obliku biti upoznati sa svojim pravima i obvezama koje proizlaze iz radnog odnosa, uključujući probni rad.

b. Prije dobivanja otkaza radnici imaju pravo biti upoznati s razlozima za njegovo dobivanje i mora im se dati razuman otkazni rok. Radnici imaju pravo pristupa djelotvornom i nepristranom rješavanju sporova, a u slučaju neopravdanog otkaza imaju pravo na pravnu zaštitu, uključujući primjerenu kompenzaciju.

\section{Socijalni dijalog i uključenost radnika}

a. Provodi se savjetovanje sa socijalnim partnerima o pripremi i provedbi gospodarskih i socijalnih politika te politika zapošljavanja u skladu s nacionalnom praksom. Potiče ih se da pregovaraju o kolektivnim ugovorima i sklapaju ih u svim područjima koja su im relevantna poštujući svoju autonomiju i pravo na kolektivno djelovanje. Prema potrebi, sporazumi koje su sklopili socijalni partneri provode se na razini Unije i njezinih država članica.

b. Radnici i predstavnici radnika imaju pravo pravovremeno biti upoznati s pitanjima koja su im relevantna te se uključiti u raspravu o njima, osobito u pogledu prijenosa, restrukturiranja i spajanja poduzeća te kolektivnog otpuštanja.

c. Potiče se potpora povećanju kapaciteta socijalnih partnera za promicanje socijalnog dijaloga.

\section{Ravnoteža između poslovnog i privatnog života}

Roditelji i osobe koje su dužne skrbiti o drugima imaju pravo na primjeren dopust, fleksibilne radne uvjete i pristup uslugama skrbi. Žene i muškarci imaju pravo jednakog pristupa posebnim dopustima za skrb i potiču se da ih jednakomjerno koriste.

\section{Zdravo, sigurno i dobro prilagođeno radno okruženje te zaštita podataka}

a. Radnici imaju pravo na visoku razinu zaštite zdravlja i sigurnosti na radu.

b. Radnici imaju pravo na radno okruženje koje je prilagođeno njihovim profesionalnim potrebama te koje će im omogućiti da što duže sudjeluju na tržištu rada.

c. Radnici imaju pravo na zaštitu osobnih podataka na radnom mjestu.

\section{POGLAVLJE III. SOCIJALNA ZAŠTITA I UKLJUČENOST}

\section{Skrb o djeci i potpora djeci}

a. Djeca imaju pravo na priuštivo predškolsko obrazovanje i na kvalitetnu skrb.

b. Djeca imaju pravo na zaštitu od siromaštva. Djeca iz ugroženih sredina imaju pravo na posebne mjere za ostvarivanje jednakih mogućnosti.

\section{Socijalna zaštita}

Bez obzira na vrstu i trajanje radnog odnosa radnici, a u usporedivim uvjetima $\mathrm{i}$ samozaposleni, imaju pravo na primjerenu socijalnu zaštitu.

\section{Naknade za nezaposlene}

Nezaposleni imaju pravo na primjerenu potporu za aktivaciju od javnih zavoda za zapošljavanje pri (ponovnom) uključivanju na tržište rada i primjerenu naknadu za nezaposlene u razumnom trajanju, u skladu s njihovim doprinosima i nacionalnim pravilima o ispunjavanju uvjeta za primanje naknade. Tim naknadama ne smije se destimulirati brz povratak na tržište rada. 


\section{Minimalni dohodak}

Svi koji nemaju dovoljno sredstava imaju pravo na primjereni minimalni dohodak koji omogućuje dostojan život u svim njegovim razdobljima te djelotvoran pristup omogućenim dobrima i uslugama. Za one koji mogu raditi minimalni bi dohodak trebalo kombinirati s poticajima za (ponovno) uključivanje na tržište rada.

\section{Dohodak u starosti i mirovine}

a. Umirovljeni radnici i samozaposleni imaju pravo na mirovinu koja odgovara njihovim doprinosima i čini primjeren dohodak. Žene i muškarci imaju jednake mogućnosti za ostvarivanje prava na mirovinu.

b. Sve starije osobe imaju pravo na resurse koji im omogućuju dostojan život.

\section{Zdravstvena skrb}

Svi imaju pravo pravovremenog pristupa priuštivoj i kvalitetnoj preventivnoj i kurativnoj zdravstvenoj skrbi.

\section{Uključenost osoba s invaliditetom}

Osobe s invaliditetom imaju pravo na dohodovnu potporu koja im osigurava dostojan život, usluge koje im omogućuju sudjelovanje na tržištu rada i u društvu te radno okruženje prilagođeno njihovim potrebama.

\section{Dugoročna skrb}

Svi imaju pravo na priuštive i kvalitetne usluge dugotrajne skrbi, osobito na usluge skrbi u domu i u zajednici.

\section{Stanovanje i pomoć beskućnicima}

a. Onima kojima je to potrebno omogućuje se pristup socijalnim stanovima ili kvalitetnoj pomoći za stanovanje. b. Ranjive osobe imaju pravo na primjerenu pomoć i zaštitu od prisilnih deložacija.

c. Osiguravaju se primjerena skloništa i usluge za beskućnike radi promicanja njihove socijalne uključenosti.

\section{Pristup osnovnim uslugama}

Svi imaju pravo pristupa kvalitetnim osnovnim uslugama, uključujući vodu, kanalizaciju, energiju, prijevoz, financijske usluge i digitalnu komunikaciju. Potpora pristupu takvih uslugama raspoloživa je onima kojima je potrebna.

\section{LITERATURA}

Europska komisija. (2013). Prema socijalnom ulaganju za rast i koheziju - uključujući i provedbu Europskog socijalnog fonda za razdoblje 2014. -2020. Revija za socijalnu politiku, 20(2), 167190. https://doi.org/10.3935/rsp.v20i2.1152

Europska komisija. (2018). Social priorities under the Juncker Commission. Dostupno na https:// ec.europa.eu/social/main.jsp?langId=en\&catId=89\&newsId=9251\&furtherNews=yes

European Trade Union Institute. (2018). Social policy in the European Union: State of play 2018. Brussels: European Trade Union Institute.

\section{Internet izvori:}

https://composite-indicators.jrc.ec.europa.eu/social-scoreboard/

https://ec.europa.eu/commission/priorities/deeper-and-fairer-economic-and-monetary-union/ european-pillar-social-rights/european-pillar-social-rights-20-principles_hr

http://ec.europa.eu/social/main.jsp?langId=en\&catId=89\&newsId=9240\&furtherNews=yes

https://www.government.se/government-policy/social-summit-for-fair-jobs-and-growth

http://ec.europa.eu/social/main.jsp?catId=1135\&lan$\mathrm{gId}=\mathrm{en}$

https://vlada.gov.hr/vijesti/predsjednik-vlade-na-social-summitu-u-goteborgu-hrvatska-snazno-podupire-europski-stup-socijalnih-prava/22868

Priredili:

Gojko Bežovan i Danijel Baturina 